\title{
二相ステンレス鋼の耐食性における介在物の影響
}

\author{
森 陽一 ${ }^{1)}$ *, 高 業飛 ${ }^{1)}$, 廖 金孫 ${ }^{1)}$, 元田慎一 ${ }^{21}$ \\ 1) 株式会社栗本鐵工所 技術開発室 \\ 2) 東京海洋大学 学術研究院 海洋電子機械工学部門
}

\section{The Influence of Inclusions on the Corrosion Resistance of Duplex Stainless Steel}

\author{
Yoichi Mori ${ }^{1}{ }^{*}$, Yefei Gao ${ }^{1)}$, Jinsun Liao ${ }^{1)}$ and Shinichi Motoda ${ }^{2)}$ \\ 1) Technology Development Department, KURIMOTO, LTD. \\ 2) Tokyo University of Marine Science and Technology
}

\begin{abstract}
*責任著者(Corresponding Author)＝559-0021 大阪市住之江区柴谷 2-8-45(2-8-45 Shibatani, Suminoe-ku, Osaka, 559-0021, Japan) E-mail: y_mori@kurimoto.co.jp
\end{abstract}

\begin{abstract}
In order to evaluate and compare the corrosion resistance of 329J3L cast steel, 329J3L rolled steel and 329J4L rolled steel, field test using sea water, immersion test and electrochemical anodic polarization test in ferric chloride aqueous solution were conducted, and inclusions in 329J3L cast steel and 329J3L rolled steel were examined with SEM/EDS. 329J4L rolled steel having the highest PRE (pitting resistance equivalent) showed the highest corrosion resistance. The corrosion resistance of 329J3L cast steel was lower than that of 329J3L rolled steel although their PRE were nearly the same. The SEM/EDS analysis revealed that the number of inclusions which could induce corrosion was much more and the size of inclusions was larger in 329J3L cast steel than in 329J3L rolled steel.
\end{abstract}

Key words : Duplex stainless steel, Cast steel, Rolled steel, Corrosion resistance, Field test, Inclusions

\section{1. 緒言}

二相ステンレス鋼はフェライト相とオーステナイト相 がおよそ1:1の比で混合した組織から成るステンレス鋼 で, オーステナイト単相のステンレス鋼と比較して，強 度が高いことに加え，少ない $\mathrm{Ni}$ 量で同等以上の耐食性 を持つ。そのため, 二相ステンレス鋼は腐食性の強い環 境にさらされる製品や部材によく用いられて，その代表 例として海水淡水化プラントの各種パイプやバルブ類な どが挙げられる。これらの製品の多くは圧延鋼板の溶接 で組み立てられるが，複雑な形状の製品では工数が増え コスト高となるため，鋳造法による製品製造が生産性向 上およびコスト低減の観点から高く期待されている。

一方，ステンレス鋼の耐食性は，主要成分だけでなく 製造方法や不純物などの影響も受けることが知られてい る $^{1)-3)}$. 例えば，圧延材よりも鋳造材の耐腐食性が劣る ことが報告され ${ }^{1)}$ ，また不純物であるリンは $100 \mathrm{ppm}$ 程 度でも粒界腐食を引き起こすとされている ${ }^{2)}$. しかしな がら，二相ステンレス鋼の耐食性影響因子についてはま だ不明な点が多い。

本研究では $329 \mathrm{~J} 3 \mathrm{~L}$ 鋳鋼，329J3L 圧延鋼および $329 \mathrm{~J} 4 \mathrm{~L}$ 圧延鋼の 3 種類二相ステンレス鋼の耐食性を比較評価 し，二相ステンレス鋳鋼と圧延鋼の耐食性相違について 介在物の視点から考察した.

\section{2. 実験方法}

本実験に用いた 329J3L 鋳鋼，329J3L 圧延鋼および

第 63 回材料と環境討論会 (大阪, 2016 年)で発表
329J4L 圧延鋼の化学成分と, 次の式 1 から求められる耐 孔食指数 PRE (Pitting resistance equivalent)を Table 1 に 示す.

$\mathrm{PRE}=\mathrm{Cr}+3.3 \mathrm{Mo}+16 \mathrm{~N}$

329J3L 鋳鋼と 329J3L 圧延鋼の PRE はほぼ同じである が，329J4L圧延鋼の PRE は 329J3L 鋳鋼または圧延鋼よ り高い.

上述の二相ステンレス鋼の耐食性を評価するため，実 海水フィールド試験, 実験室における浸漬試験およびア ノード分極試験を行った。これらの実験に用いた $329 \mathrm{~J} 3 \mathrm{~L}$ 鋳鋼試験片は厚さ $30 \mathrm{~mm}$ の $\mathrm{Y}$ 型ブロックに鋳造したも のから，329J3L 圧延鋼と 329J4L圧延鋼試験片は厚さ $30 \mathrm{~mm}$ の圧延鋼板から，それぞれ切り出した。試験片へ 加工する前に，これらの二相ステンレス鋼に対して溶体 化処理を実施し, 熱処理後の冷却は水中で行ったため, シグマ相などの金属間化合物が析出しなかった。

フィールド試験は東京海洋大学水圈科学フィールド教 育研究センター清水ステーション(静岡県静岡市清水区) に設置された一過性流動水槽にて行った。孔食試験片の 寸法は, $329 \mathrm{~J} 3 \mathrm{~L}$ 鋳鋼は $120 \times 75 \times 3 \mathrm{~mm}, 329 \mathrm{~J} 4 \mathrm{~L}$ 圧延鋼 は $100 \times 60 \times 3 \mathrm{~mm}$ で, 表面を\#1500の耐水研磨紙で研 磨した。すき間腐食試験片の寸法は，329J3L 鋳鋼および $329 \mathrm{~J} 4 \mathrm{~L}$ 圧延鋼ともに $50 \times 50 \times 3 \mathrm{~mm}$ で, 中央に直径 8 mmの穴をあけ，表面を\#1500 の耐水研磨紙で研磨し， 片面あたり 20 箇所のすき間を作る Fig. 1 に示すような PTFE 製治具で試験片を両面から挟み, M6 のボルト, ナットおよびスプリングワッシャー用いて $3 \mathrm{Nm}$ で締結 した。これらの試験片を上記水槽に 1 年間浸漬して評価 した.

実験室における浸漬試験では 329J3L 鋳鋼，329J3L 圧 延鋼および $329 \mathrm{~J} 4 \mathrm{~L}$ 圧延鋼を対象に，塩化鉄水溶液による 
Table 1 Chemical compositions of the stainless steels used in this study

\begin{tabular}{cccccccccccc}
\hline & & $\mathrm{C}$ & $\mathrm{N}$ & $\mathrm{Si}$ & $\mathrm{Mn}$ & $\mathrm{P}$ & $\mathrm{S}$ & $\mathrm{Ni}$ & $\mathrm{Cr}$ & $\mathrm{Mo}$ & PRE*1 \\
\hline \multirow{3}{*}{ 329J3Ly } & Cast & 0.020 & 0.17 & 0.36 & 1.20 & 0.016 & 0.006 & 5.84 & 22.92 & 2.86 & 35.08 \\
\cline { 2 - 11 } & Rolled & 0.011 & 0.16 & 0.54 & 1.78 & 0.026 & 0.000 & 5.78 & 22.50 & 3.07 & 35.19 \\
\cline { 2 - 11 } & Specification $* 2$ & $\leq 0.030$ & $0.08 \sim 0.20$ & $\leq 1.00$ & $\leq 2.00$ & $\leq 0.040$ & $\leq 0.030$ & $4.50 \sim 6.50$ & $21.00 \sim 24.00$ & $2.50 \sim 3.50$ & - \\
\hline \multirow{2}{*}{$329 \mathrm{J4L}$} & Rolled & 0.011 & 0.15 & 0.65 & 0.82 & 0.027 & 0.000 & 7.07 & 25.12 & 3.07 & 37.65 \\
\cline { 2 - 10 } & Specification $* 2$ & $\leq 0.030$ & $0.08 \sim 0.30$ & $\leq 1.00$ & $\leq 1.50$ & $\leq 0.040$ & $\leq 0.030$ & $5.50 \sim 7.50$ & $24.00 \sim 26.00$ & $2.50 \sim 3.50$ & - \\
\hline
\end{tabular}

$※ 1$ PRE(Pitting resistance equivalent $)=\mathrm{Cr}+3.3 \mathrm{Mo}+16 \mathrm{~N}$ $※ 2$ JIS G4304
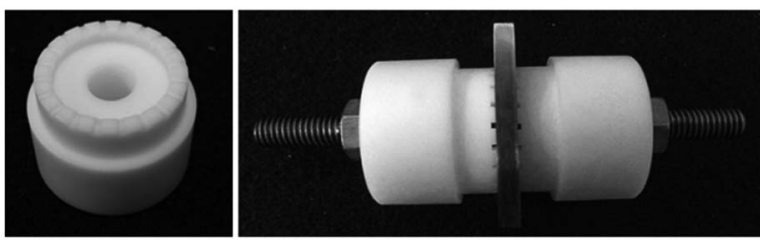

Fig. 1 Crevice washer and assembly

すき間腐食試験を行った。試験片寸法は $30 \times 30 \times 3 \mathrm{~mm}$ で，中央に直径 $8 \mathrm{~mm}$ の穴をあけ，表面は $\mathrm{Ra}=1.2 \mu \mathrm{m}$ 程 度の機械研磨仕上げとした，上記フィールド試験で用い たものと同様のすき間形成治具を用いて $0.28 \mathrm{Nm}$ のトル クで締結した。この試験片を $22^{\circ} \mathrm{C}$ に保持した 6 mass $\%$ の $\mathrm{FeCl}_{3}$ 水溶液に $72 \mathrm{~h}$ 浸漬し，発生したすき間腐食箇所 の数を評価した。

アノード分極試験は，\#4000 の耐水研磨紙で研磨した後 $1 \mu \mathrm{m}$ のダイヤモンド懸濁液を用いて羽布研磨を行った試 験片の $4 \mathrm{~mm}^{2}$ が露出するようにマスキングテープで覆 い, 6 mass\% の $\mathrm{FeCl}_{3}$ 水溶液に浸漬 10 分後, $20 \mathrm{mV} / \mathrm{min}$ の掃引速度で浸漬電位からアノード分極を行った。温度 は $22^{\circ} \mathrm{C}$ であった。

アノード分極前後の光学顕微鏡像を比較し, 分極後に 発生した孔の付近を走査型電子顕微鏡 $(\mathrm{SEM})$ を用いて 観察し, 介在物を SEM 付属のエネルギー分散型 X 線分 析 (EDS)にて解析した.

二相ステンレス鋼中の介在物の寸法と分布の解析は,
上記手順で羽布研磨を行った $329 \mathrm{~J} 3 \mathrm{~L}$ 鋳鋼および圧延鋼 について $1.2 \times 0.9 \mathrm{~mm}$ の視野で SEM 観察を行い, 得ら れた反射電子 (COMPO) 像を OLYMPUS analySIS FIVE を用いて画像解析により行った。観察された介在物の面 積と個数を階級幅 $25 \mu \mathrm{m}^{2}$ でプロットして介在物寸法分 布曲線を得た．各鋼種について 3 視野ずつ解析し，介在 物の数は 3 視野の合計とした.

\section{3. 結果と考察}

\section{1 フィールドにおける海水浸漬試験}

一年間実海水に浸漬した孔食試験片の外観を Fig. 2 に 示す。右側の貫通穴は試験片吊り下げのためのものであ る。一部海洋生物の付着が見られるものの, 329J4L 圧延 鋼だけではなく $329 J 3 L$ 鋳鋼でも孔食が見られなかった.

一年間浸漬したすき間腐食試験片の外観とすき間腐食発 生個所の解析結果を Fig. 3 に示す. 図中の数字は分母が 形成されたすき間の数で, 分子がすき間腐食の発生数で ある. 329J4L 圧延鋼と比べて $329 \mathrm{~J} 3 \mathrm{~L}$ 鋳鋼のすき間腐食 の発生数が非常に多かった.

Table 1 から分かるように 329J3L 鋳鋼および 329J4L 圧延鋼の PRE はそれぞれ 35.08 および 37.65 である。両 者の海水における耐すき間腐食性の違いは主にPREの 違いによるものと思われるが，後述のように鋳造と圧延 という製法の違いの影響も受けていると考えられる。

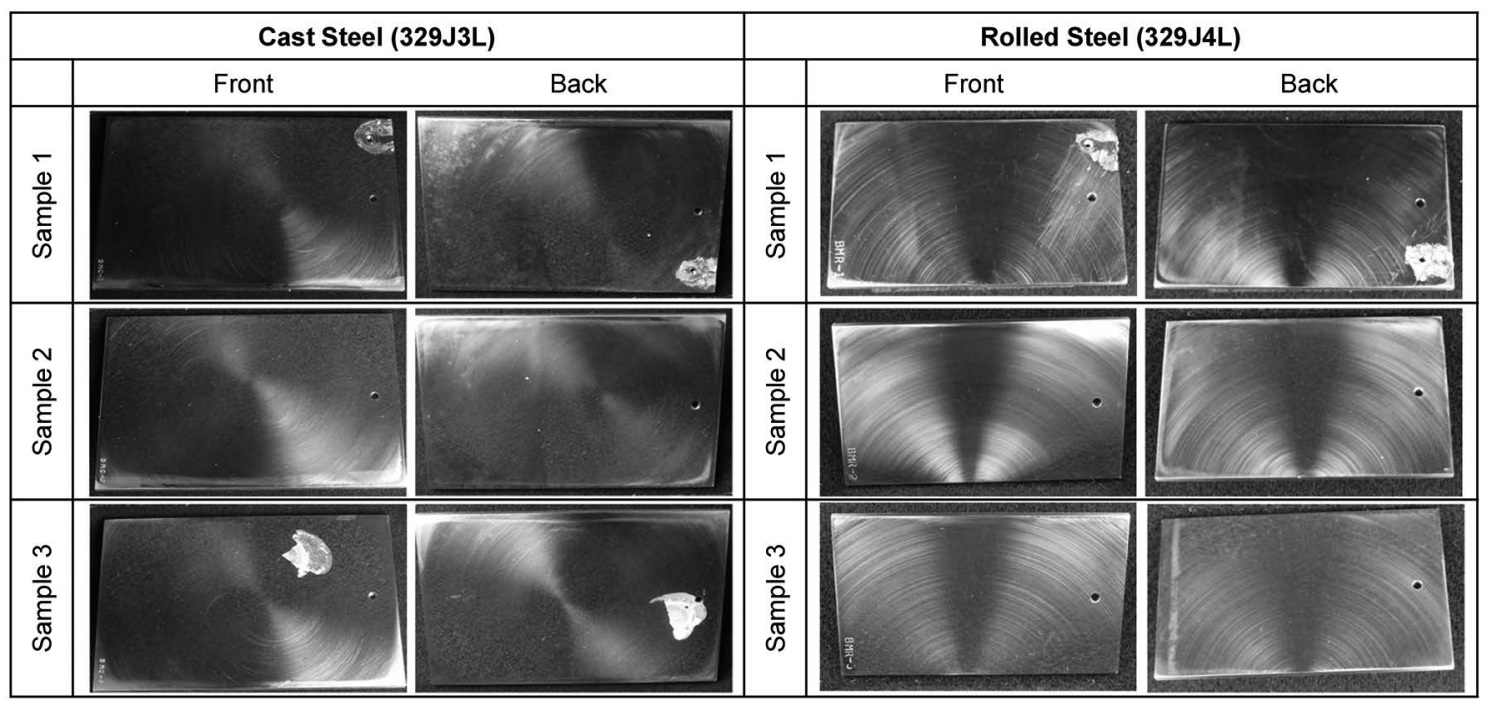

Fig. 2 Appearance of specimens after pitting corrosion experiment in sea water for 1 year 


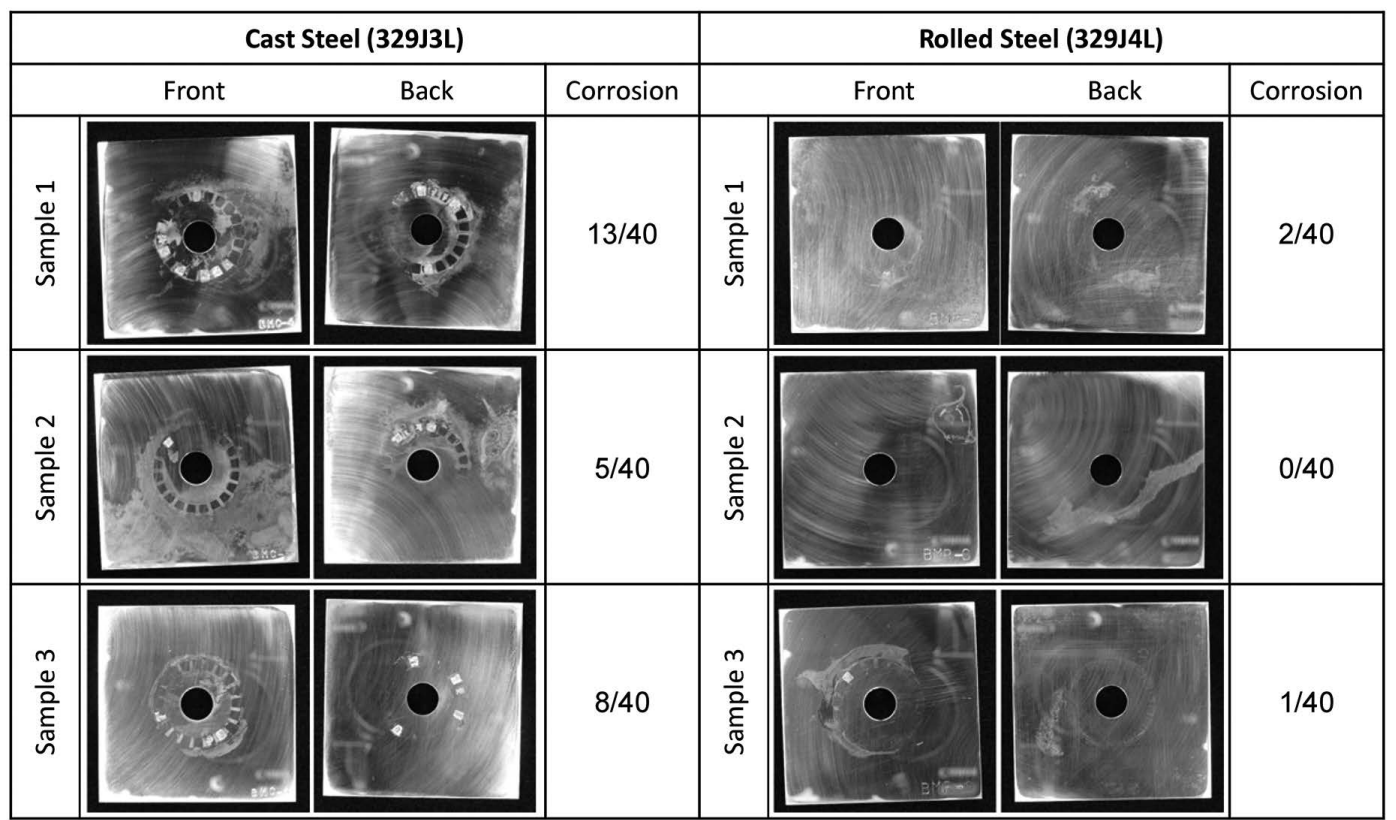

Fig. 3 Appearance of specimens after crevice corrosion experiment in sea water for 1 year

\section{2 実験室における塩化鉄水溶液浸漬試験}

ASTM G48-03（2009）に基づき 329J3L 鋳鋼，329J3L 圧延鋼㧍よび $329 \mathrm{~J} 4 \mathrm{~L}$ 圧延鋼の 6 mass\%塩化鉄水溶液に よるすき間腐食試験の結果を Fig. 4 に示す。329J3L 鋳鋼 のすき間腐食発生数の 32 に対して, 329J3L圧延鋼のす き間腐食発生数が 24 であったことから，329J3L 鋳鋼の 耐すき間腐食性は329J3L圧延鋼より劣ることが分かる。 また，329J4L圧延鋼ではすき間腐食は見られなかった。

329J4L圧延鋼の優れた耐食性は高い PRE 值によるも のと考えられるが，329J3L 鋳鋼と 329J3L 圧延鋼はほぼ 同じPRE を有しているにもかかわらず，329J3L圧延鋼 の耐食性が 329J3L 鋳鋼より高い。その原因の一つとし て，後述のように，鋼材中における介在物の種類と寸法 の相違が挙げられる.

\begin{tabular}{|c|c|c|c|c|}
\hline & PRE & Front & Back & Corrosion \\
\hline 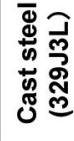 & 35.08 & & & $32 / 40$ \\
\hline 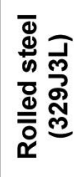 & 35.19 & & & $24 / 40$ \\
\hline 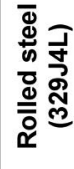 & 37.65 & 0 & (3) & $0 / 40$ \\
\hline
\end{tabular}

Fig. 4 Appearance of specimens after crevice corrosion experiment in 6 mass $\% \mathrm{FeCl}_{3}$ solution for $72 \mathrm{~h}$

\section{3 アノード分極}

$329 \mathrm{~J} 3 \mathrm{~L}$ 鋳鋼と圧延鋼の耐食性を比較検討するために, 6 mass\%水溶液中でアノード分極を行った。アノード分 極曲線を Fig. 5 に示す. 329J3L 鋳鋼を圧延鋼と比較する と，329J3L 鋳鋼のアノード分極曲線に多くのパルスが見 られた。

アノード分極曲線に見られたパルスは主に孔食の発生 と修復によるもので, $329 \mathrm{~J} 3 \mathrm{~L}$ 鋳鋼中の介在物に起因した 可能性が高いと推測している。パルス高さがほほ一定と なっているのは，分極時の電流レンジは自動であったも ののパルス電流の急増に追随しきれていなかった可能性 が考えられる。高電位側ではパルスが見られなくなり， 329J3L鋳鋼と 329J3L圧延鋼の電流密度はほほ一致した。

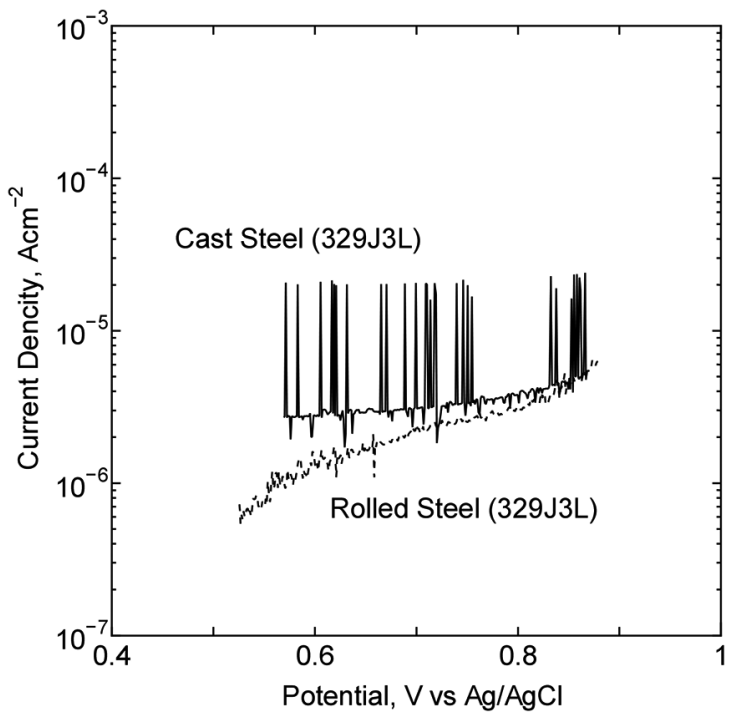

Fig. 5 Polarization curves of the cast and rolled 329J3L stainless steels. 


\section{4 介在物の解析}

\#4000 の耐水研磨紙での研磨に続き $1 \mu \mathrm{m}$ のダイヤモ ンド懸濁液を用いて羽布研磨した後に, シュウ酸エッチ ングを行った $329 J 3 \mathrm{~L}$ 鋳鋼に対してアノード掃引を行い, $0.85 \mathrm{~V} \mathrm{vs} \mathrm{Ag} / \mathrm{AgCl}$ に達したところで掃引を終了して直ち に光学顕微鏡にて観察を行った。このアノード分極前後 を比較した光学顕微鏡観察像を Fig. 6 に示す. 矢印は分 極後に出現した孔を示す。この像から，掃引後に多数の 孔が出現したことが分かる. 出現した孔の一部を SEM/ EDS にて観察した結果の一例を Fig. 7 に示す。 介在物 は，オーステナイト相(a)，フェライト相(b)抢よびそれ らの境界 $(\mathrm{c})$ いずれの場所にも見られた。アノード分極 時の溶解はこれらの介在物と周辺母相との境界付近で起 きていることが分かる. 介在物周辺の EDS による元素 分析の結果を Fig. 8 に示す. 分析位置 021, 022, 023, 024 はそれぞれ介在物，分極で溶解したと思われる孔，フェ ライト相，オーステナイト相に対応する. 介在物からは $\mathrm{Al}, \mathrm{Mn}, \mathrm{O}$ などが検出され, 溶解した部分からは $\mathrm{S}$ と $\mathrm{Mn}$ が検出された. MnS が腐食の起点となることはよく 知られており ${ }^{4)}, \mathrm{S}$ 含有量が規格值を大幅に下回る 57 ppm 以下であっても 304 鋼において孔食を発生させると の報告がある ${ }^{5}$. しかし分析位置 022 の孔は $\mathrm{MnS}$ にし ては Mn に対する S の存在比がかなり高い. $\mathrm{MnS}$ のア ノード溶解により $\mathrm{MnS}$ と周辺との境界部に元素状の $\mathrm{S}$ が析出することが報告されて抢り ${ }^{6)}$ ，そのために見かけ 上 $\mathrm{Mn}$ 量に対する $\mathrm{S}$ 量が多くなったと考えられる.

アノード分極を行っていない $329 \mathrm{~J} 3 \mathrm{~L}$ 鋳鋼掞よび圧延 鋼の介在物をSEMにより観察した結果を Fig. 9 に示す. これらの像は反射電子による組成像である。(a)-(c) は
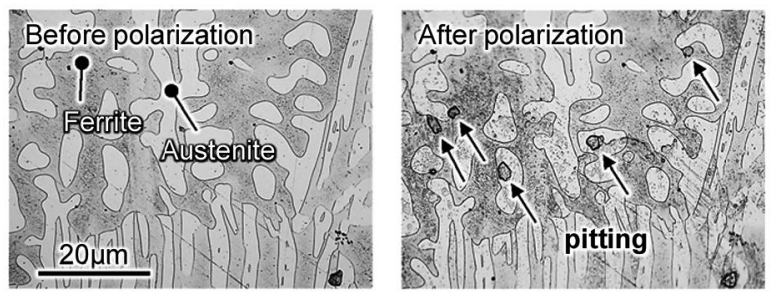

Fig. 6 Microstructures of cast stainless 329J3L steel before and after polarization.
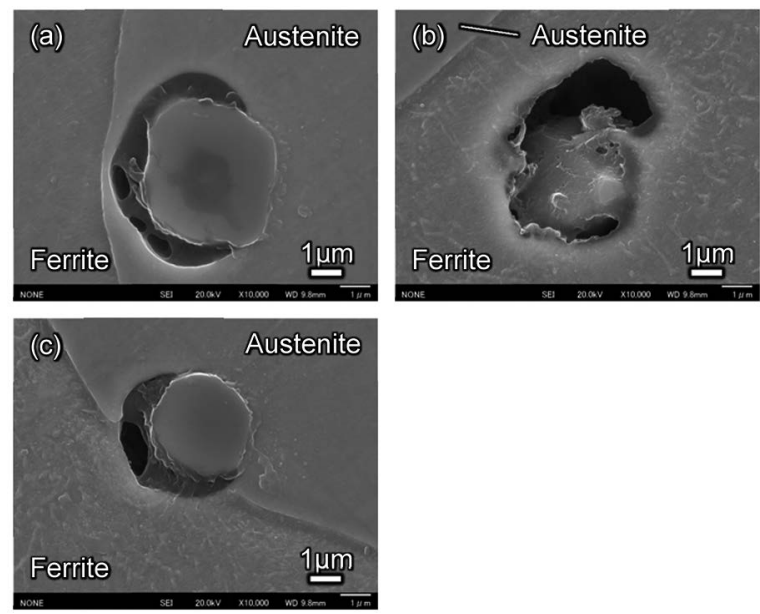

Fig. 7 Corrosion pits appeared on cast 329J3L stainless steel after polarization.
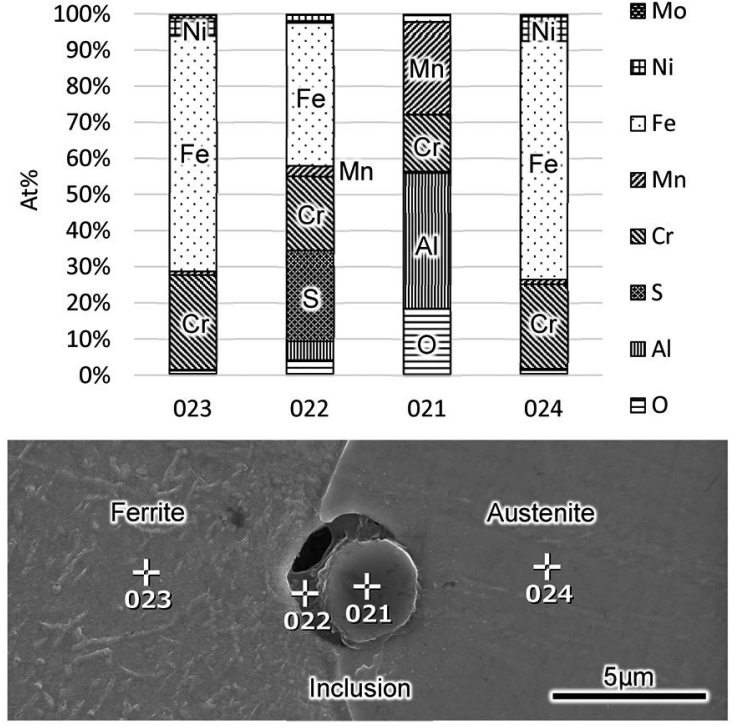

Fig. 8 Chemical compositions around the inclusion initiated pitting corrosion.
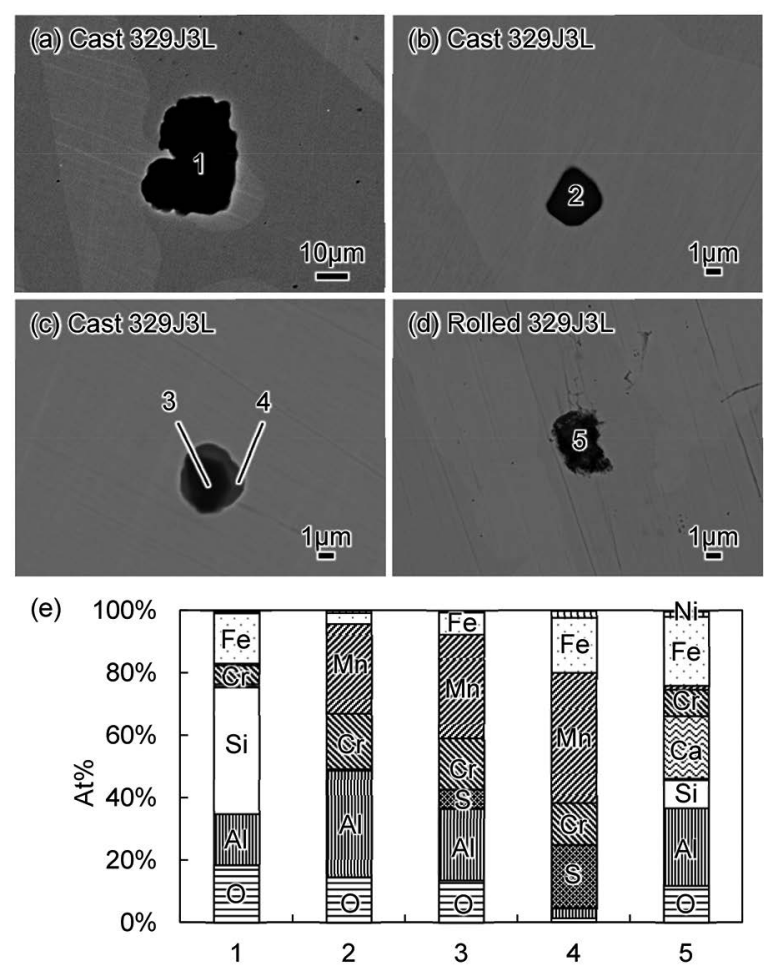

Fig. 9 Inclusions and their compositions in the cast and rolled 329J3L stainless steels.

329J3L 鋳鋼の介在物, (d) は 329J3L 圧延鋼の介在物であ る. SEM 像中の数字で表される領域についての EDSに よる分析結果を (e)に示す. SEM 像 (a)の粒子 1 からは 主に $\mathrm{Al}, \mathrm{Si}, \mathrm{O}$ が, SEM 像(b)の粒子 2 からは Fig. 8 と 同じく $\mathrm{Al}, \mathrm{Mn}, \mathrm{O}$ などが検出された. $\mathrm{Al}, \mathrm{Mn}$ および $\mathrm{Si}$ は鉄の脱酸剤として添加されたものと思われる. SEM 像 (c) には複数の相からなる粒子が見られる。領域 3 か らは(b)の領域 2 と同様に $\mathrm{Al}, \mathrm{Mn}, \mathrm{O}$ などが検出され, 領域 4 からは主に Mn と S が検出されている。このよう な酸化物と硫化物の二相からなる介在物は鋼においてし ばしば見られる ${ }^{7)}$ 。この粒子はアノード分極を行うと 
Fig. 8 で示されたように S を含む部分で溶解を起こすと考 えられる. $329 \mathrm{~J} 3 \mathrm{~L}$ 圧延鋼からは 1 種類の介在物しか検出 されなく，その主な組成は SEM 像(d)の粒子 5 のように $\mathrm{Al}, \mathrm{Ca}, \mathrm{Si}, \mathrm{O}$ であったが, $\mathrm{S}$ を含む粒子は検出できなか った.この種の介在物については $\mathrm{Al}, \mathrm{Ca}, \mathrm{Si}$ 系の酸化物 が耐食性にほとんど影響を及ばさない報告と ${ }^{8)}, \mathrm{Mg}, \mathrm{Al}$, $\mathrm{Ca}$ 系の酸化物が孔食の起点になるという報告 ${ }^{9)}$ がある.

介在物の分布状態を調べるため，329J3L 鋳鋼および圧 延鋼について介在物の画像解析を行った. $329 \mathrm{~J} 3 \mathrm{~L}$ 鋳鋼と圧 延鋼の金属組織の SEM 反射電子像を Fig. 10 に示す。(a) は 329J3L 鋳鋼，（b) は 329J3L 圧延鋼の金属組織である. オーステナイト相とフェライト相は組成が異なるため ${ }^{10)}$, 異なる明るさを示している. すなわち, 明るい部分がオー ステナイト相，やや暗い部分がフェライト相である. 所々 に見える黒いものを介在物として画像処理を行った結果を Fig. 11 に示す. 329J3L 圧延鋼に比べて, 329J3L 鋳鋼中の 介在物が大きいことが分かる．その理由として圧延鋼では 圧延の過程で介在物が細かく砕かれるためと考えられる.

前述の実験室における耐すき間腐食試験結果から分か るように，329J3L 鋳鋼は 329J3L 圧延鋼より耐食性が劣
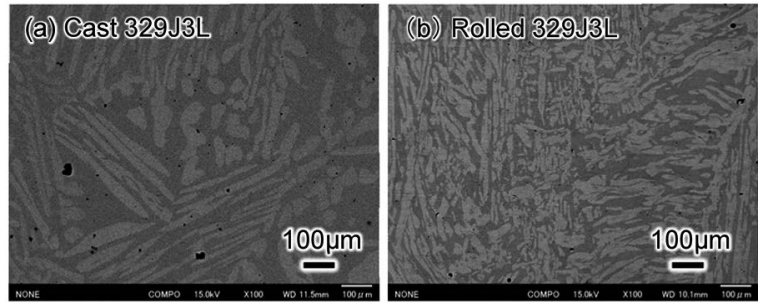

Fig. 10 Microstructures of the cast and rolled 329J3L stainless steels.

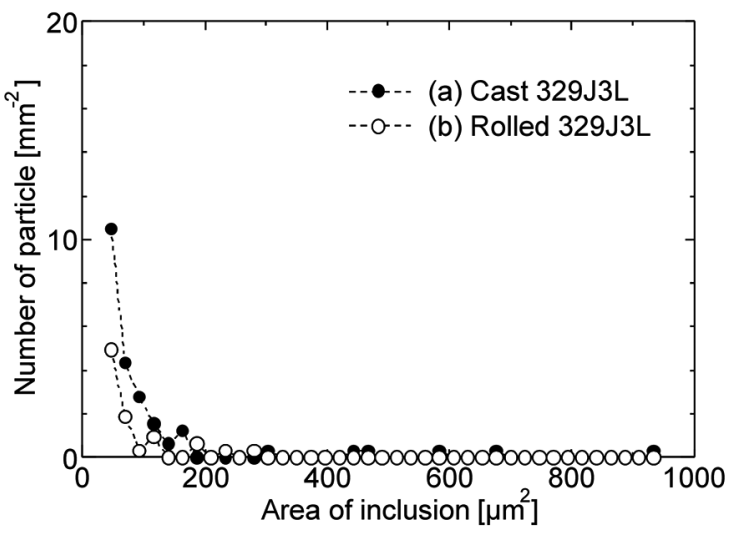

Fig. 11 Particle size distribution of the inclusions exposed on the cast and rolled 329J3L stainless steels.
っている.アノード分極後の試験片表面を観察した結 果, 介在物の周辺に孔食が発生しやすいことが分かっ た.また，329J3L 鋳鋼と圧延鋼中の介在物の種類が異な り，329J3L 鋳鋼中に腐食起点になり得る介在物が多かっ た.さらに, 329J3L圧延鋼に比べて, 329J3L 鋳鋼中の 介在物が大きかった．介在物が小さい場合は孔も浅く周 辺部の溶解により介在物が離脱し, 孔食進行が停止しゃ すいが ${ }^{11)}$, 介在物が大きい場合は孔も深くなり介在物が 離脱した後も孔食が自己触媒的に進行すると思われる. 本研究に用いられた $329 \mathrm{~J} 3 \mathrm{~L}$ 鋳鋼と圧延鋼の耐食性相違 は介在物による可能性が高いと考えらえる。

\section{4. 結 論}

本研究ではフィールドにおける海水浸漬試験, 実験室 における塩化鉄水溶液浸漬試験およびアノード分極試験 を用いて，329J3L 鋳鋼，329J3L 圧延鋼および 329J4L 圧 延鋼の耐食性を比較評価した。また，329J3L 鋳鋼と圧延 鋼中の介在物を調査し，両者の耐食性の相違に及ぼす介 在物の影響を考察した. 329J4L 圧延鋼は 329J3L 鋳鋼と 329J3L 圧延鋼より PRE が高いため，耐食性が優れてい た. PRE がほぼ同じの 329J3L 鋳鋼と 329J3L 圧延鋼で は, 前者のほうがより耐食性が劣る理由の一つとして, $329 \mathrm{~J} 3 \mathrm{~L}$ 鋳鋼中に腐食起点になり得る介在物が多く，また 介在物のサイズが大きかったことが考えられた。

\section{参 考 文 献}

1) M. Miyasaka, Ebara Engineering Review, 224, p.28-37 (2009).

2) J.S.Armijo, Corrosion, 24, pp.24-30 (1968).

3) Jinsun Liao, ISIJ International, 41 [5] pp.460-467 (2001).

4) M. Smialowski, Z. Szklarska-Smialowska, M. Rychcik and A. Szummer, Corrosion Science, 9, p.123 (1969).

5) Tomoaki Saida, Sohei Nakai, Katsuaki Sato, Kensuke Kuroda and Masazumi Okido, Zairyo-to-Kankyo, 62 [7] p.259 (2013).

6) A. Chiba, I. Muto, Y. Sugawara and N. Hara, J. Electrochem. Soc., 160, C511-C520 (2013).

7) S. K. Choudhary and A. Ghosh, ISIJ International, 48 [11] pp.1552-1559 (2008)

8) Kazumi Kakimoto, Kazushige Kidena and Kazuo Nakama, Sanyo Technical Report, 8 [1] pp.27-33 (2001).

9) Shuqi Zheng, Chunyu Li, Yameng Qi, Liqiang Chen and Changfeng Chen, Corrosion Science, 67, pp.20-31 (2013).

10) Hiroo Nagano and Masamichi Kowaka, Tetsu-to-Hagané, 66 [8] pp.1150-1159 (1980).

11) R. Ke and R. Alkire, J. Electrochemical Society, 142, pp.4056-4062 (1995).

(Manuscript received November 21, 2016; in final form February 9, 2017)

329J3L 鋳鋼，329J3L 圧延鋼および 329J4L 圧延鋼の 3 種類の二相ステンレス鋼の耐食性を比較評価する ため, フィールドにおける海水浸漬試験，実験室における塩化鉄水溶液浸漬試験およびアノード分極試験 を実施し，329J3L 鋳鋼と圧延鋼中の介在物を SEM/EDS にて観察解析した．PRE が最も高い 329J4L 圧延 鋼は耐食性が最も優れていた. 329J3L 鋳鋼と 329J3L圧延鋼については, PRE はほぼ同じであっても前者 のほうがより耐食性が劣っていた．介在物を調査したところ，329J3L 鋳鋼中には 329J3L 圧延鋼よりも腐 食起点になり得る介在物が多く，また介在物のサイズが大きかった.

キーワード二相ステンレス鋼，鋳鋼，圧延鋼，耐食性，フィールド試験，介在物 